\title{
The Collective Teacher Efficacy Behaviours Scale: A Validity and Reliability Study
}

\section{Seyfettin Kapat ${ }^{(1}$, Sevilay Sahin ${ }^{(2}$, Mevlut Kara ${ }^{(3)}{ }^{3}$ *}

\author{
${ }^{1}$ Republic of Turkey, Ministry of Education, Gaziantep, Turkiye \\ ${ }^{2}$ Gaziantep University, Faculty of Education, Department of Educational Sciences, Gaziantep, Turkiye \\ ${ }^{3}$ Gaziantep University, Nizip Faculty of Education, Department of Educational Sciences, Gaziantep, Turkiye
}

\begin{abstract}
ARTICLE HISTORY
Received: June 1, 2021

Revised: Nov. 29, 2021

Accepted: Jan. 13, 2022

Keywords:

Collective efficacy

behaviours,

Teacher,

Scale,

Scale development,

Social cognitive theory.

Abstract: The concept of collective efficacy that can be defined as "a belief in their common ability to organize and realize plans to achieve goals" (Bandura, 1997, p. 477) has gained utmost importance in educational contexts. Therefore, there arises an emergent need to develop scales to evaluate teachers' collective efficacy behaviours. To this end, the present study aimed to develop an instrument to assess collective teacher efficacy behaviours. For this purpose in mind, an item pool was created in line with the related literature and face-to-face interviews with teachers. Two participating groups were included in the study. There was a total of 833 participants, 475 of which were in the first group and 358 in the second group. The preliminary version of The Collective Teacher Efficacy Behaviours Scale (CTEBS), consisted of 26 items. Exploratory Factor Analysis (EFA) and Confirmatory Factor Analysis (CFA) were employed to test the construct validity of the scale with the available datasets. As a result of the EFA, a two-factored structure, namely social and professional relationship and professional development, was identified with 20 items. The two factors explained $58.798 \%$ of the total variance. Confirmatory factor analysis (CFA) was used to test the validity of the structure based on the EFA results. It was found that the CFA fit indices were $\chi^{2} / d f=3.174, \mathrm{RMSEA}=.076, \mathrm{SRMR}=.435, \mathrm{NFI}=.902, \mathrm{CFI}=.930, \mathrm{IFI}=.931$, and GFI $=.872$. The results implied that The Collective Teacher Efficacy Behaviours Scale, consisting of two dimensions and 20 items, was a valid and reliable instrument.
\end{abstract}

\section{INTRODUCTION}

Human beings, as social entities, may overcome difficult tasks, adapt to society, and accelerate personal and professional development more easily with a collective lifestyle. The individuals' faster integration into society and their concordant actions are directly related to their acceptance by society. In this regard, individuals tend to meet their requirements to communicate effectively and act in cooperation with their environment. Similarly, individuals need to coexist with such concerns as preventing potential problems, improving working conditions, and increasing the existing level of achievement (Demir, 2019). Individuals who act together and support each other may be more effective and efficient in solving the problems

\footnotetext{
*CONTACT: Mevlut KARA \mevlutkara85@gmail.com 크 Gaziantep University, Nizip Faculty of Education, Department of Educational Sciences, Gaziantep, Turkiye
} 
they are likely to encounter. Collective power is supposed to arise among the individuals working together if they meet those requirements. Direct and indirect learning may emerge as a result of the relationships between individuals in organizations based on a collective understanding. The development and consequences of social relations between individuals is an area of interest for social cognitive theory. According to the mutual causality principle of social cognitive theory, individual and organizational factors mutually affect each other in organizations (Kurt, 2012). From this point of view, Bandura (1982) discussed the concept of collective efficacy, which implies a greater phenomenon than the sum of self-efficacies in an organization, and pointed out that people never live in isolation from the social environment and some hard work can only be achieved through working together.

The literature review introduces a great many definitions for the concept of collective efficacy. Bandura (1997) embraced the concept of collective efficacy from an organizational perspective and defined it as "a belief in their common ability to organize and realize plans to achieve goals" (p. 477). Tschannen-Moran and Barr (2004) dealt with this notion in terms of schools as educational organizations and described it as "a school characteristic that creates a difference on students' schooling, unlike teachers' self-efficacy" (p. 190). The main goal of schools is to improve the quality of education and training and ultimately increase student achievement. In the harsh conditions of our age, it is far from reality for teachers to increase student achievement solely with their separate efforts (Y1lmaz \& Turanl, 2017). It is of great importance that teachers support each other and act in harmony for in-school activities in order to be more effective and efficient during the educational processes. The creation of an organization with collective efficacy depends on employees' support for each other, teamwork, cooperation (Y1lmaz \& Uslu, 2018), and solidarity (Demir, 2019).

From the perspective of student outcomes, Abedini et al. (2018) identified the concept of collective efficacy as "the educators' perceptions for their ability to positively affect student outcomes" (p. 2). Goddard et al. (2000) characterized it as "the interactive product of the group members at school for student achievement" (p. 483). As collective efficacy includes interactive, coordinated, and synergistic social dynamics unlike self-efficacy (Yorulmaz \& Erdem, 2017), the concept of collective efficacy becomes even more and more important for school climate and the school outcomes concerning student achievement. Collective teacher efficacy has started to be frequently investigated, especially in educational studies, because of its positive effects on school outcomes (Koçak \& Özdemir, 2019). Goddard et al. (2000) asserted that teachers are more effective on students at schools with high collective teacher efficacy. Collective efficacy, which is an organizational characteristic of schools (Schechter \& Tschannen-Moran, 2006) is a phenomenon that positively or negatively affects cooperative teacher behaviours (Lee et al., 2011), instructional school decisions (Goddard, 2002), higher expectations and openness to new ideas (Donohoo, 2018), and their performance qualities (Abedini et al., 2018). In terms of students' academic development, it can be alleged that schools with high collective efficacy may positively affect students' development (Belfi et al., 2015), result in student learning and achievement (Eells, 2011; Goddard et al., 2000), significantly predict the level of success between schools (Goddard, 2002), reduce the negative effects of students' sociodemographic variables (Ramos et al., 2014), and help teachers motivate their students better (Erdoğan \& Dönmez, 2015).

Collective teacher efficacy is significant not only for student achievement (Goddard, 2002; Tschnann-Moran \& Barr, 2004) but also in terms of teachers' job satisfaction, commitment to their students, positive attitudes towards students, and professional development (Donohoo, 2018). Strengthening collective efficacy at schools would be possible with the development of co-working behaviours, the adoption of school vision by teachers, getting everyone's ideas and 
opinions in problem-solving, creating encouraging environments for student learning, and teachers' keeping themselves up to date (Turhan \& Yaraş, 2014).

An examination of the related literature shows that a great many instruments have been developed to measure collective efficacy perceptions (Schwarzer \& Jarusalem, 1999; Goddard et al., 2000; Goddard, 2002; Tschannen-Moran \& Barr, 2004; Carroll et al., 2005; Pepe et al., 2008; Kurt, 2009; Erdoğan \& Dönmez, 2015; Abedini et al., 2018). The social cognitive theory asserts that there are differences between people's levels of perception and their behaviours, that is, not every piece of knowledge and skill could be observed explicitly (Kurt, 2009). In this regard, the present study focused on measuring collective teacher efficacy behaviours, unlike their levels of perception, with a specific purpose to contribute to the relevant literature by developing a valid and reliable instrument to assess collective teacher efficacy behaviours. Besides, this scale is considered as the development of first original in the Turkish context concentrating on teachers' collective efficacy behaviours.

\section{METHOD}

In this part of the study, the scale development procedures for Collective Teacher Efficacy Behaviours Scale (CTEBS) are explained in detail. During this process, the following stages proposed by DeVellis (2017) were followed:

- Determining the behaviours to be assessed,

- Creating an item pool,

- Determining the measurement method,

- Taking the opinions of field experts,

- Implementing the scale,

- Analysing the items,

- Finalizing the scale based on the analyses.

\subsection{Study Group}

The research data were collected from two different groups and at different times in the academic year of 2020-2021. Exploratory Factor Analysis (EFA) was employed on the dataset of the first study group and Confirmatory Factor Analysis (CFA) was performed on the dataset of the second study group. The teachers in the study groups were active at schools. The demographics of the first and second study groups are presented in Table 1.

According to data in Table 1, it can be asserted that both sample groups were similar as the percentages of the variables for the first group in which the EFA was employed and the second group in which the CFA was performed were quite close to each other. Besides, exploratory factor analysis and correlation analysis were performed on the dataset of the first study group, while confirmatory factor analysis, 27\% lower-upper group analysis, Cronbach's alpha, and composite reliability analysis were performed on the dataset of the second study group. 
Table 1. The demographics of the first and second study groups.

\begin{tabular}{llllllll}
\hline & First Study Group & \multicolumn{6}{c}{ Second Study Group } \\
\hline Variable & Group & $\mathrm{N}$ & $\%$ & Variable & Group & $\mathrm{N}$ & $\%$ \\
\hline \multirow{2}{*}{ Gender } & Female & 261 & 54.9 & \multirow{2}{*}{ Gender } & Female & 203 & 56.7 \\
& Male & 214 & 45.1 & & Male & 155 & 43.3 \\
\hline \multirow{3}{*}{ Age } & $22-30$ & 206 & 43.4 & & $22-30$ & 167 & 46.6 \\
& $31-40$ & 193 & 40.6 & \multirow{2}{*}{ Age } & $31-40$ & 127 & 35.5 \\
& $41-50$ & 64 & 13.5 & & $41-50$ & 51 & 14.2 \\
& 51 and over & 12 & 2.5 & & 51 and over & 13 & 3.6 \\
\hline \multirow{3}{*}{ Level of } & Associate & 4 & 0.8 & & Associate & 6 & 1.7 \\
education & Bachelor & 415 & 87.4 & Level of & Bachelor's & 311 & 86.9 \\
& Master & 53 & 11.2 & education & Master's & 37 & 10.3 \\
& PhD & 3 & 0.6 & & PhD & 4 & 1.1 \\
\hline \multirow{3}{*}{ Professional } & $1-5$ & 215 & 45.3 & & $1-5$ & 160 & 44.7 \\
seniority & 6-10 & 96 & 20.2 & Professional & $6-10$ & 60 & 16.8 \\
& $11-20$ & 120 & 25.3 & seniority & $11-20$ & 102 & 28.5 \\
& 20 and over & 44 & 9.3 & & 20 and over & 36 & 10.1 \\
\hline \multirow{3}{*}{ School type } & Primary school & 176 & 37.1 & & Primary school & 141 & 39.4 \\
& Secondary school & 175 & 36.8 & School type & Secondary school & 129 & 36.0 \\
& High school & 124 & 26.1 & & High school & 88 & 24.6 \\
\hline
\end{tabular}

\subsection{Scale Development Process}

An item pool was initially created to assess collective teacher efficacy behaviours. During the formation of the item pool, both the literature was reviewed and the teachers were interviewed. A 41-item pool was created as a result of the review of related literature (Abedini et al., 2018; Bandura, 1997; Blatti et al., 2019; Borgogni et al., 2010; Çelik et al., 2018; Donohoo, 2017; Donohoo et al., 2018; Eells, 2011; Goddard et al., 2000; Goddard et al., 2004; Guskey \& Passaro, 1994; Gürçay et al., 2009; Kurt, 2009; Özcan, 2017; Parker et al., 2006; Ross et al., 2003; Ross \& Bruce, 2007; Schwarzer \& Jarussalem, 1999; Turhan \& Yaraş, 2014; Uğurlu et al., 2018; Ware \& Kistantas, 2007; Y1lmaz \& Uslu, 2018; Yorulmaz \& Erdem, 2017) and face to face interviews with 19 teachers individually.

A draft version of the instrument was developed based on the item pool. Three experts in the field of educational administration were consulted to examine the content validity of the draft version. The experts were asked to choose among the options of "appropriate, should be improved, and inappropriate" and were encouraged to express their opinions under the option of "explanations". Büyüköztürk et al. (2018) uttered that the necessary arrangements should be made in case the items are unsatisfactory, and the inappropriate ones should be removed based on expert opinions. Accordingly, the scale was reduced to 26 items after the exclusion of 15 items that were deemed to be inappropriate for measuring similar behaviours by the experts. For the face validity, the 26-item draft form was edited by two assistant professors who are experts in the field of the Turkish language. A pilot scheme was conducted with 22 teachers to determine the level of understandability of the draft scale, which was finalized in line with their feedback.

A five-point Likert-type grading was used to determine whether teachers agree with the items in the scale. The options in the scale were "1- Do not agree at all, 2-Disagree, 3- Neutral, 4Agree, and 5- Completely agree". 


\subsection{Data Collection}

The research data were collected during the Covid 19 pandemic in 2021. Due to the closure of the schools, the computer-assisted survey was formed to reach the teachers. The instrument consisted of three sections. The first part included the purpose of the study and an informed consent section where the participants declared their voluntary participation in the study. The second part consisted of five questions (gender, age, level of education, professional seniority, and school type) to determine their demographics. And in the third part a 26-item scale was given.

In the beginning, the sample size for the analyses was determined. While Nunally (1978) asserted that reaching a sample of 10 times the number of items would be sufficient, Tabachnick and Fidell (2001) pointed out that the sample size of 300 was acceptable and that of 1000 was perfect. In this regard, 475 participants were included in the first study group for the 26 -item version and 358 participants were covered in the second study group for the 20-item version based on the statistical analyses for the first group data. The research data were collected in December 2020. Before the analyses, the research data were examined and a total of 17 surveys were excluded as the presence of outliers in the data set would affect the correlation size (Best \& Kahn, 2017).

\subsection{Data Analysis}

At the first step, the EFA was employed to determine the construct validity of the draft version of the scale. Principal Axis Factoring (PAF) was used in the EFA since the researcher may prefer the principal axis factoring method to understand the latent variables among the observed ones (Karaman et al., 2017). This method also yields a composite result by combining the common and unique variables (Karaman, 2015). On the other hand, Tabachnick and Fidel (2012) specified that promax rotation may be preferred since the results to be obtained by a researcher to perform oblique rotation would be more applicable than the direct oblimin rotation for the future. In this regard, promax rotation was chosen among oblique rotation methods while performing exploratory factor analysis. Tabachnick and Fidel (2012) suggested that the factor loadings should be greater than .32 for the item to be a member of any factor. The present study conforms to the aforementioned criteria.

The CFA was employed to test and verify the structure obtained as a result of the EFA. There are a great many indices in the CFA to reveal the compliance of the structure. This study examined the chi-square goodness test, Goodness of Fit Index (GFI), Adjusted Goodness of Fit Index (AGFI), Comparative Fit Index (CFI), Parsimony Normed Fit Index (PNFI), Parsimonious Goodness of Fit Index (PGFI), Normed Fit Index (NFI), Incremental Fit Index (IFI), the Root Mean Square Error of Approximation (RMSEA), and Standardized Root Mean Square Residual (SRMR).

In order to test the criterion validity, the relationship between the current scale and the Collective Teacher Efficacy Scale (CTES) adapted by Erdoğan and Dönmez (2015) was examined. The reliability of the data was tested through Cronbach's Alpha and composite reliability methods. SPSS 22.0, AMOS 21, and Microsoft Excel were used for all calculations in the study. The composite reliability coefficient was estimated with formula-1 using path coefficients and error variances obtained from the CFA.

$$
C R=\frac{\left(\sum_{i=1}^{n} \lambda_{i}\right)^{2}}{\left(\sum_{i=1}^{n} \lambda_{i}\right)^{2}+\left(\sum_{i=1}^{n} \delta_{i}\right)}
$$




\section{FINDINGS}

Findings regarding the validity and reliability of The Collective Teacher Efficacy Behaviours Scale are presented in this section. The EFA and the CFA were employed to test the construct validity of the data obtained by using the CTEBS.

\subsection{Exploratory Factor Analysis}

The suitability of the dataset for the analyses was initially examined to employ the exploratory factor analysis. To that end, KMO and Bartlett's sphericity tests were conducted. KMO test is supposed to be greater than 0.60 and the Bartlett sphericity test is to be significant for the adequacy of sample size (İslamoğlu \& Alnıaçık, 2016). Kalaycı (2006) affirmed that the KMO coefficient over 0.90 indicates a perfect dataset for analysis. In this study, the KMO coefficient was estimated to be 0.966 , and Bartlett's test of sphericity $\left(x^{2}=9619,895, d f=325, p<.000\right)$ was found to be significant. Based on these, the dataset was determined to be convenient for the analysis.

Büyüköztürk (2002) pointed out that the eigenvalues should be scrutinized, the factors with a score greater than 1 should be assumed valid, and the line graph (scree plot) for the factor eigenvalues should be reviewed to determine the number of factors. On the other hand, Uyar (2012) noted that the most consistent criterion in determining the number of factors is parallel analysis while Pallant (2007) asserted that parallel analysis results should be included in the process of reporting the findings of studies in the fields of education and psychology. This method was used in the present study as it is claimed that the number of factors should be determined with the parallel analysis method (Brown, 2006). Table 2 indicates the factor eigenvalues of the draft version of the scale and the factor eigenvalues after the parallel analysis.

Table 2. The findings of EFA and parallel analysis eigenvalues.

\begin{tabular}{cccc}
\hline Factor & EFA Eigenvalues & PA Eigenvalues & Conclusion \\
\hline 1 & 14.050 & 1.455 & Accepted \\
2 & 1.715 & 1.384 & Accepted \\
3 & 1.306 & 1.333 & Rejected \\
\hline
\end{tabular}

Factors with eigenvalues of and above 1 are considered noteworthy in factor analysis (Pedhazur \& Pedhazur Schmelkin, 1991). In determining the factors through parallel analysis, it is necessary to compare the eigenvalues of the real dataset with the randomly selected data and exclude factors up to the point where the eigenvalues of the real data are greater than those of the random data (Akbaş et al., 2019). When Table 2 is examined according to the aforementioned criteria, it can be seen that the first and second factors were accepted since the EFA eigenvalues were higher than those of the parallel analysis were. It can be explained that the scree plot, which is used as an auxiliary graph to decide the number of factors, will be cut in the area where the points are flattened and the following eigenvalues will be small and approximate (Çokluk et al., 2012). Graph 1 displays the results of the analyses. It was obvious that the slope in the line graph decreased significantly after the second factor. When the factor eigenvalues and scree plot were considered together, it was concluded that the scale could have a two-factor structure. 
Graph 1. Scree plot.

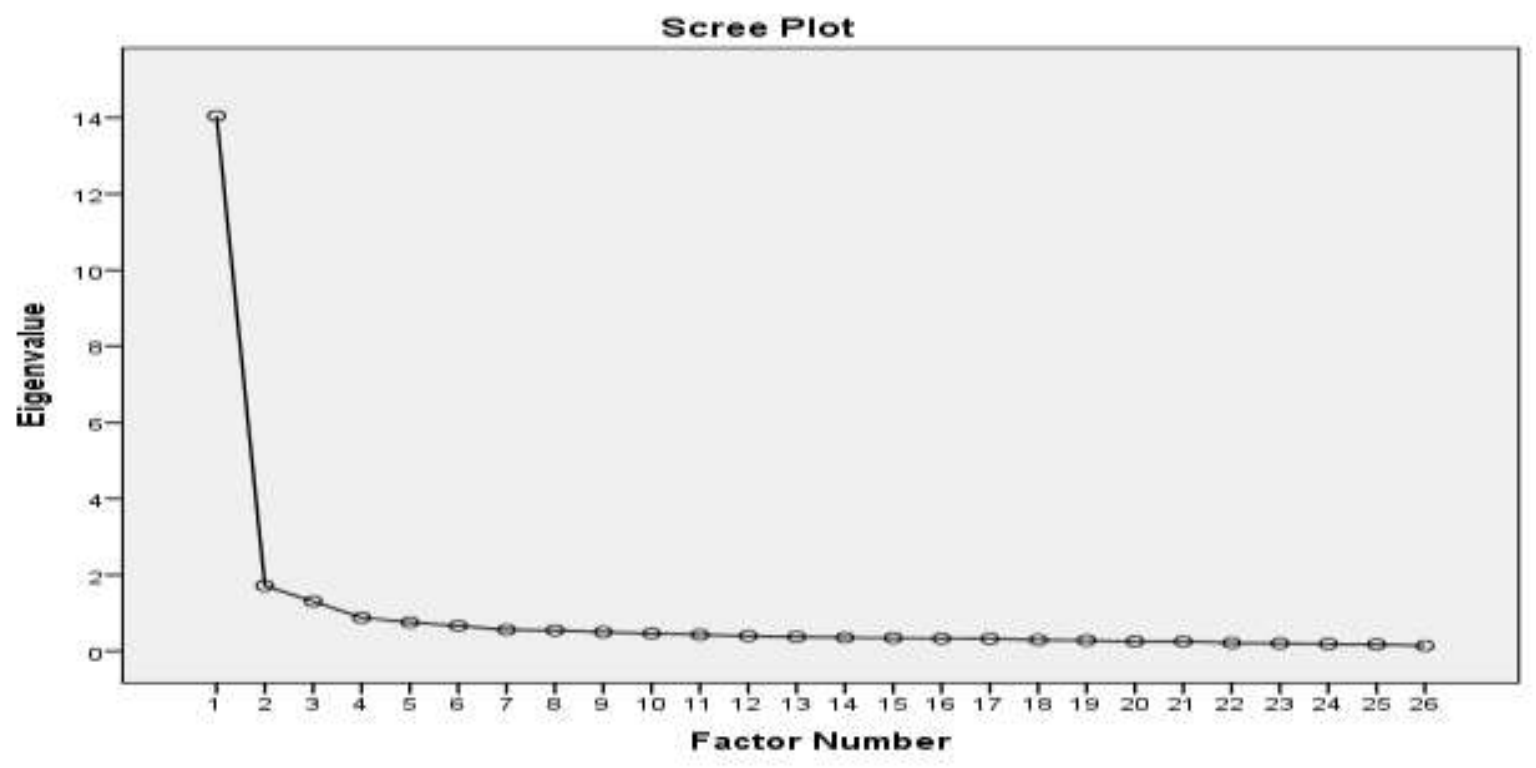

Table 3. Item factor loadings.

\begin{tabular}{|c|c|c|}
\hline \multirow[b]{2}{*}{ Item No } & \multicolumn{2}{|c|}{ Factor } \\
\hline & 1 & 2 \\
\hline i12 & .868 & \\
\hline i18 & .803 & \\
\hline i10 & .782 & \\
\hline i21 & .773 & \\
\hline i9 & .741 & \\
\hline i19 & .739 & \\
\hline i23 & .737 & \\
\hline i24 & .687 & \\
\hline i11 & .672 & \\
\hline i15 & .666 & \\
\hline i8 & .664 & \\
\hline i16 & .646 & \\
\hline $\mathrm{i} 22$ & .636 & \\
\hline $\mathrm{i} 20$ & .633 & \\
\hline i13 & .631 & \\
\hline i26 & .580 & \\
\hline i14 & .547 & \\
\hline i7 & & .954 \\
\hline i5 & & .907 \\
\hline i2 & & .838 \\
\hline i1 & & .774 \\
\hline i4 & & .736 \\
\hline i3 & & .634 \\
\hline $\mathrm{i} 25$ & & .481 \\
\hline i6 & .374 & .467 \\
\hline i17 & .339 & .406 \\
\hline
\end{tabular}


According to Table 3, the item factor loadings varied between .339 and .954 . The analysis results implied that there were statistical problems associated with item overlapping between the factors. Regarding the item overlap correlation, Büyüköztürk (2012) suggested that the difference between two high loadings should be .10 at least. Moreover, the lower limit of the item factor loadings was determined to be .32 in factor analysis (Tabachnick \& Fidel, 2001). In this vein, the analyses were reiterated by respectively excluding the overlapping items (i6 and i17) and those deemed to be incompatible with the factors based on expert opinion (m8, i14, i23, and i25). The emergent structure is presented in Table 4. According to Table 4, a structure consisting of two factors and 20 items was obtained as a result of the reiterated EFA. The factor loadings of the items varied between .499 and .919 .

Table 4. EFA loadings after the exclusion of items threatening construct validity.

\begin{tabular}{cccc}
\hline Item & & \multicolumn{2}{c}{ Factor Loadings } \\
\cline { 2 - 4 } No & Common Variance & Factor 1 & Factor 2 \\
\hline i12 & .722 & .908 & \\
i18 & .639 & .825 & \\
i21 & .717 & .824 & \\
i10 & .578 & .780 & \\
i9 & .698 & .736 & \\
i19 & .437 & .704 & \\
i11 & .568 & .673 & \\
i13 & .625 & .651 & \\
i15 & .528 & .617 & \\
i16 & .579 & .601 & \\
i22 & .533 & .554 & \\
i24 & .433 & .543 & .499 \\
i26 & .472 & & .865 \\
i20 & .340 & & .811 \\
i7 & .752 & & .751 \\
i5 & .736 & & .669 \\
i2 & .595 & & \\
i1 & .614 & & \\
i4 & .617 & & \\
i3 & .575 & & \\
Explained Total Variance: \%58.798 & & \\
& & & \\
\hline
\end{tabular}




\subsection{Factor Labelling}

The factors of the EFA were re-examined in terms of the expression of the items and the factors were labelled as in Table 5.

Table 5. Factor labelling.

\begin{tabular}{|c|c|c|c|}
\hline \multirow{2}{*}{ Factor } & \multirow{2}{*}{$\begin{array}{l}\text { Number } \\
\text { of Items }\end{array}$} & \multirow{2}{*}{ Items } & Sample items \\
\hline & & & All of us as teachers ... \\
\hline $\begin{array}{l}\text { Social and } \\
\text { Professional } \\
\text { Relationship } \\
\text { (SPR) }\end{array}$ & 14 & $\begin{array}{c}9,10,11,12,13,15 \\
16,18,19,20,21,22 \\
24,26\end{array}$ & $\begin{array}{l}\ldots \text { are with our fellow teachers in their special } \\
\text { occasions and hard times. } \\
\ldots \text { unite when a colleague of us is exposed to an } \\
\text { unfairness. }\end{array}$ \\
\hline $\begin{array}{l}\text { Professional } \\
\text { Development } \\
\text { (PD) }\end{array}$ & 6 & $1,2,3,4,5,7$ & $\begin{array}{l}\text {... keep ourselves up to date to ensure our } \\
\text { professional development. } \\
\text {... make every attempt for our students' academic } \\
\text { achievement. }\end{array}$ \\
\hline
\end{tabular}

\subsection{Confirmatory Factor Analysis}

In the confirmatory factor analysis, the researcher tests the hypothesis suggested based on theoretical grounds (Balc1, 2016). The CFA was employed to determine the compliance of the emergent two-dimensional structure with 20 items as a result of the EFA. Crowley and Fan (1997) recommended that various fit indices should be used as parameters in the CFA. In this vein, fit indices and the results based on the CFA are submitted in Table 6.

Table 6. Acceptable indices and the results of the CFA.

\begin{tabular}{ccccc}
\hline Fit Index & Index & Perfect Fit & Acceptable Fit & Result \\
\hline$\chi^{2} / d f$ & 3.174 & $0<\chi^{2} / d f \leq 3$ & $3<\chi^{2} / d f \leq 5$ & Acceptable Fit \\
RMSEA & .076 & $.00 \leq$ RMSEA $\leq .05$ & $.05<$ RMSEA $\leq .08$ & Acceptable Fit \\
SRMR & .0435 & $0<$ SRMR $\leq .05$ & $.05<$ SRMR $\leq .10$ & Perfect Fit \\
CFI & .930 & $.95 \leq \mathrm{CFI} \leq 1.00$ & $.90 \leq \mathrm{CFI} \leq .95$ & Acceptable Fit \\
GFI & .872 & $.90 \leq \mathrm{GFI} \leq 1.00$ & $.85 \leq \mathrm{GFI} \leq 90$ & Acceptable Fit \\
NFI & .902 & $.95 \leq \mathrm{NFI} \leq 1.00$ & $.90 \leq \mathrm{NFI} \leq .95$ & Acceptable Fit \\
IFI & .931 & $.95 \leq \mathrm{IFI} \leq 1.00$ & $.90 \leq \mathrm{IFI} \leq .95$ & Acceptable Fit \\
PNFI & .797 & $.95 \leq \mathrm{PNFI} \leq 1.00$ & $.50 \leq \mathrm{PNFI} \leq .95$ & Acceptable Fit \\
PGFI & .698 & $.95 \leq \mathrm{PGFI} \leq 1.00$ & $.50 \leq \mathrm{PGFI} \leq .95$ & Acceptable Fit \\
\hline
\end{tabular}

When the reference ranges of the indices in Table 6 and the results for the dataset were examined together, it was clear that the two-factor model had an acceptable fit (Bentler \& Bonett, 1980; Byrne \& Campell, 1999; Schumacker \& Lomax, 2010; Tabachnick \& Fidel, 2012; Doğan, 2013; İlhan \& Çetin, 2014; Karagöz, 2017). The path diagram for the model and factor loadings based on the CFA are presented in Figure 1. 
Figure 1. Path diagram for the model and factor loadings based on the CFA.

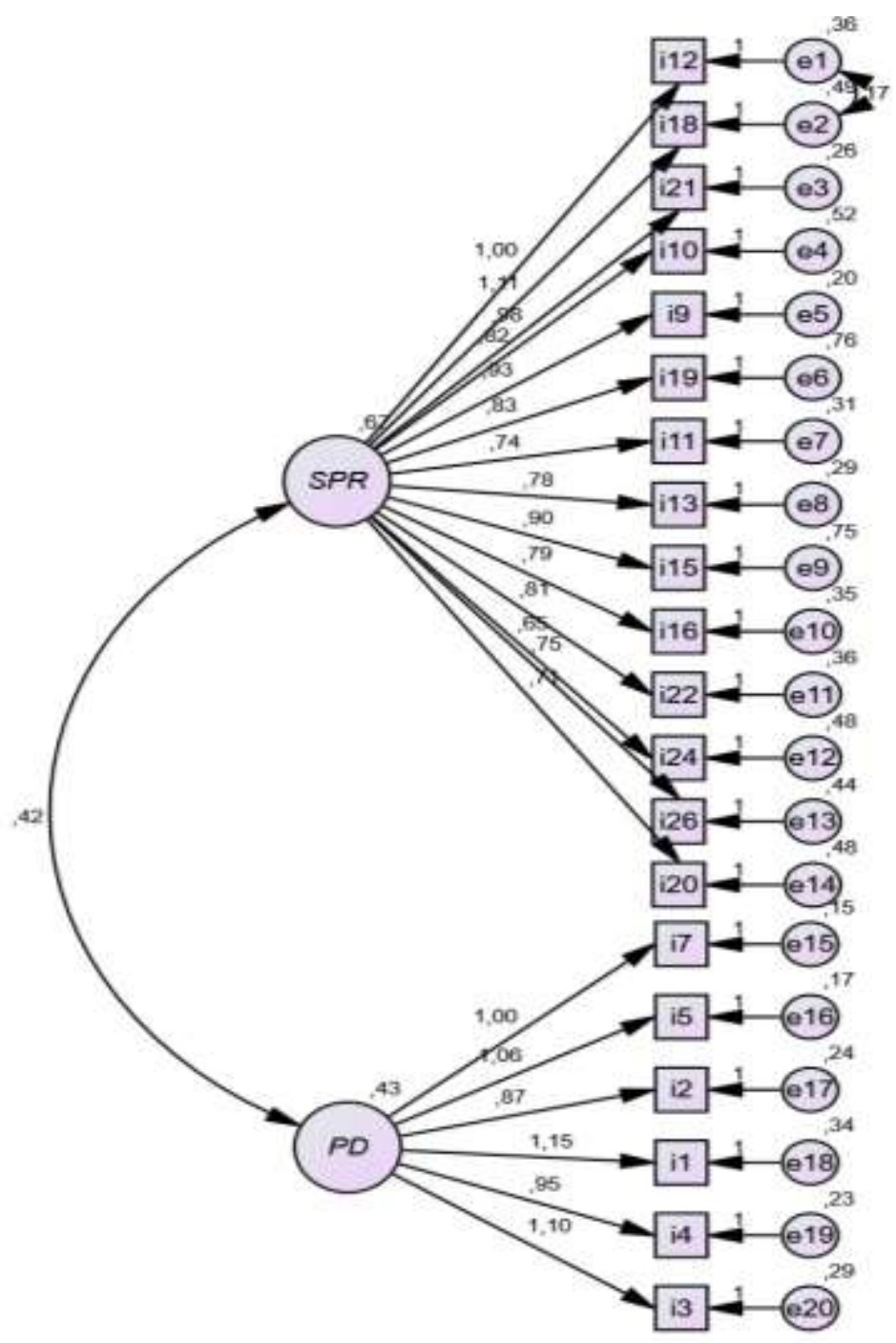

As a result of the CFA, the structure consisting of a total of 20 items, 14 of which are in the Social and Professional Relationship dimension and 6 of them in the Professional Development dimension, was confirmed. As can be seen in Figure 1, factor loadings ranging from .61 to .86 for the sub-dimensions support the model fit.

\subsection{Criterion Validity}

The correlation coefficients between The Collective Teacher Efficacy Behaviours Scale (CTEBS) and the Collective Teacher Efficacy Scale (CTES) adapted by Erdoğan and Dönmez (2015) were analysed with the data obtained from 53 teachers within the scope of criterion validity. The results are presented in Table 7.

Table 7. Criterion validity findings.

\begin{tabular}{lccc}
\hline & CTES & Student Discipline & Instructional Strategies \\
\hline CTEBS & .069 & .047 & .083 \\
Social and Professional Relationship & .074 & .051 & .088 \\
Professional Development & .008 & .003 & .012 \\
\hline
\end{tabular}

An examination of Table 7 indicates that the correlation coefficient between the CTEBS and CTES is .069 and ranges from .003 to .088 for the dimensions. This finding implies that CTES, focusing on the collective perceptions of teachers, and CTEBS, concentrating on collective behaviours, intend to assess different aspects. 


\subsection{Reliability}

The reliability of the emergent scale was determined through Cronbach's alpha and composite reliability coefficients. The scores are given in Table 8 .

Table 8. Reliability coefficients for CTEBS.

\begin{tabular}{lcc}
\hline Factors & Cronbach's Alpha & Composite Reliability \\
\hline Social and Professional Relationship & .912 & .939 \\
Professional Development & .919 & .853 \\
Overall & .938 & .962 \\
\hline
\end{tabular}

As displayed in Table 8, Cronbach's Alpha coefficient of .938 for the overall scale, .912 for the Social and Professional Relationship dimension, and .919 for the Professional Development dimension were estimated. On the other hand, composite reliability coefficients were computed based on the factor loadings and error variances in the CFA. Composite reliability coefficients were determined as .962 for the overall scale, .939 for the Social and Professional Relationship dimension, and .853 for the Professional Development dimension. As the reliability coefficients over .70 indicate that an instrument is reliable (Liu, 2003), it can be alleged that the reliability coefficients for CTEBS are satisfactorily high in our study.

\subsection{Item Analysis}

Lower-upper group item analysis was conducted to determine item discrimination (Tezbaşaran, 1997). In this vein, independent samples t-test was performed for the lower $(n=97)$ and upper $(n=97)$ groups, based on rankings according to the highest and lowest scores for each item, and the item-total correlations are submitted in Table 9.

Table 9. Item-total correlations and lower-upper group item analysis results.

\begin{tabular}{cccc}
\hline Item No & Item Total Correlation & $t$ & $p$ \\
\hline $\mathrm{i} 1$ & .701 & 15.226 & .000 \\
$\mathrm{i} 2$ & .653 & 11.735 & .000 \\
$\mathrm{i} 3$ & .720 & 15.525 & .000 \\
$\mathrm{i} 4$ & .730 & 13.691 & .000 \\
$\mathrm{i} 5$ & .734 & 15.222 & .000 \\
$\mathrm{i} 7$ & .714 & 14.316 & .000 \\
$\mathrm{i} 9$ & .824 & 18.825 & .000 \\
$\mathrm{i} 10$ & .736 & 13.937 & .000 \\
$\mathrm{i} 11$ & .752 & 13.540 & .000 \\
$\mathrm{i} 12$ & .816 & 19.841 & .000 \\
$\mathrm{i} 13$ & .792 & 13.280 & .000 \\
$\mathrm{i} 15$ & .748 & 13.042 & .000 \\
$\mathrm{i} 16$ & .774 & 13.830 & .000 \\
$\mathrm{i} 18$ & .788 & 2.573 & .011 \\
$\mathrm{i} 19$ & .652 & 12.633 & .000 \\
$\mathrm{i} 20$ & .618 & 11.987 & .000 \\
$\mathrm{i} 21$ & .826 & 19.636 & .000 \\
$\mathrm{i} 22$ & .745 & 13.510 & .000 \\
$\mathrm{i} 24$ & .686 & 11.560 & .000 \\
$\mathrm{i} 26$ & .708 & 13.627 & .000 \\
\hline
\end{tabular}

An examination of the findings in Table 9 yields that $t$ values for 20 items in the scale are between 2.573 and 19.841. Accordingly, the significance of $t$ values implies that the items are discriminatory. It can also observed that the item-total correlations vary between .652 and .826 , 
which implies that each item is coherent with the scale. The examination of item analysis for the lower-upper groups results indicate that all the items in the scale have a high level of reliability and item discriminations are significant (Büyüköztürk, 2012).

\section{DISCUSSION and CONCLUSION}

This study aimed to develop a valid and reliable instrument for collective teacher efficacy behaviours. For this purpose, the scale development stages suggested by DeVellis (2017) were followed. In this vein, a pool of 41 items was initially created by reviewing the relevant literature and interviewing the teachers. 30 items in the pool were created based on the literature review (Abedini et al., 2018; Bandura, 1997; Bandura, 2000; Blattivd, 2019; Borgogni et al., 2010; Çelik et al., 2018; Donohoo, 2017; Eells, 2011; Goddard et al., 2000; Goddard et al., 2004; Gürçay et al., 2009; Kurt, 2009; Kurt, 2012; Lee \& Smith, 1996; Parker et al., 2006; Ross et al., 2003; Schwarzer \& Jarussalem, 1999; Tschannen-Moran \& Barr, 2004; Turhan \& Yavaş, 2014; Ware \& Kistantas, 2007; Y1lmaz \& Uslu, 2018; Yorulmaz \& Erdem, 2017), and 11 items were based on the interviews with the teachers. Expert opinion was taken for the content and face validity of the scale. Based on the expert opinions, 15 items were eliminated and a 26-item draft scale was created. A five-point Likert-type grading including "do not agree at all, disagree, neutral, agree, and completely agree" was used for the items in the scale.

Exploratory factor analysis (EFA) and confirmatory factor analysis (CFA) were employed to test the construct validity of the CTEBS. As a result of the first EFA, the overlapping two items (items 6 and 17) and theoretically incompatible four items (items 8, 14, 23, and 25) with the dimensions were respectively excluded and the EFA was reemployed. As a result of the second EFA, a two-factor structure consisting of 20 items and explaining $58.798 \%$ of the total variance was obtained. The factors were labelled as Social and Professional Relationship and Professional Development in line with the relevant literature. Bandura (1997) highlighted that individuals working in a group cannot be socially isolated from group members and Goddard et al. (2000) asserted that collective teacher efficacy is a result of the emergent interactive dynamics within a group. Therefore, the first factor was labelled as "social and professional relationship". On the other hand, Parker et al. (2006) pointed out that collective efficacy is a crucial factor for explaining the differences in student achievement and expertise by experience is essential in improving student achievement. Considering that collective efficacy affects student success in the classroom (Ross \& Gray, 2006) by conducting the necessary activities to create positive student outcomes (Goddard et al., 2004), the second factor was labelled as "professional development".

The CFA was employed to determine whether the model based on the EFA was verified or not. The fit indices were reported together with the model (path diagram in Figure 1) based on the CFA. It was observed that the fit indices were within acceptable limits, and a two-factor model consisting of 20 items was confirmed. The examination of the EFA and the CFA results implied that the scale developed had construct validity. On the other hand, the "Collective Teacher Efficacy Scale" adapted by Erdoğan and Dönmez (2015) was used as a criterion and the correlation coefficients between the overall scores of the two scales and their dimensions were estimated to test the criterion validity of the scale. According to the results of statistical analysis, it was concluded that CTEBS and CTES assessed different aspects of collective efficacy.

Cronbach's Alpha, composite reliability coefficient, and 27\% lower-upper item analysis were computed to test the reliability of the data obtained by using the CTEBS. Cronbach's Alpha coefficient of .938 for the overall scale, .912 for the Social and Professional Relationship dimension, and .919 for the Professional Development dimension were found. Composite reliability coefficients were determined as .939 for the Social and Professional Relationship dimension, and .853 for the Professional Development dimension. The reliability coefficients 
over .70 indicate that the instrument is reliable (Liu, 2003; Tezbaşaran, 1997). Moreover, it was concluded that all the items were discriminatory based on the $27 \%$ lower-upper group analysis conducted to determine the distinctiveness of the items in the CTEBS.

The findings revealed that the CTEBS (Appendix 1) is a valid and reliable instrument to be used to test the collective efficacy behaviours of teachers working in primary, secondary, and high schools. For future studies, it may be suggested that the validity of the scale should be tested on preschool teachers as a different sample group. Considering the theoretical background of collective teacher efficacy, its relationship with such variables as organizational culture, academic achievement, leader-member exchange, teacher leadership, and organizational citizenship can be scrutinized.

\section{Declaration of Conflicting Interests and Ethics}

The authors declare no conflict of interest. This research study complies with research and publishing ethics. The scientific and legal responsibility for manuscripts published in IJATE belongs to the authors. Ethics Committee Number: Gaziantep University/Institute of Educational Sciences, E-39083294-050.06-185

\section{Authorship Contribution Statement}

Seyfettin Kapat: Investigation, Resources, Methodology, Visualization, Software, Data Collection, Formal Analysis, and Writing the Original Draft. Sevilay Sahin: Framing, Methodology, Supervision, and Validation. Mevlut Kara: Framing, Data Collection, Investigation, Methodology, Supervision and Validation, Software, Formal Analysis, and Writing the Original Draft.

\section{Orcid}

Seyfettin Kapat (iD https://orcid.org/0000-0003-2211-3025

Sevilay Sahin (D) https://orcid.org/0000-0002-7140-821X

Mevlut Kara (DiD https://orcid.org/0000-0002-6381-5288

\section{REFERENCES}

Abedini, F., Bagheri, M.S., \& Sadighi, F. (2018). Exploring Iranian collective teacher efficacy beliefs in different ELT settings through developing a context-specific English language teacher collective efficacy scale. Cogent Education, 5(1), 1552340. https://doi.org/10.10 80/2331186X.2018.1552340

Akbaş, U., Karabay, E., Yıldırım-Seheryeli, M., Ayaz, A., \& Demir, Ö.O. (2019). Türkiye ölçme araçları dizininde yer alan açımlayıcı faktör analizi çalışmalarının paralel analiz sonuçları ile karşılaştırılması [Comparison of exploratory factor analysis studies in Turkish measurement tools index according to parallel analysis results]. Kuramsal Eğitimbilim Dergisi, 12(3), 1095-1123. https://doi.org/10.30831/akukeg.453786

Bandura, A. (1997). Self-efficacy: The exercise of control. Freeman.

Bandura, A. (1982). The assessment and predictive generality of self-percepts of efficacy. Journal of Behavior Therapy and Experimental Psychiatry, 13(3), 195-199. https://doi.org/10.1016/0005-7916(82)90004-0

Bandura, A. (2000). Exercise of human agency through collective efficacy. Current Directions in Psychological Science, 9(3), 75-78. https://doi.org/10.1111/1467-8721.00064

Balc1, A. (2016). Sosyal bilimlerde araştırma yöntem, teknik ve ilkeler (12. Bask1) [Research methods, techniques and principles in social sciences (12. Bask1)]. Pegem Akademi.

Belfi, B., Gielen, S., De Fraine, B., Verschueren, K., \& Meredith, C. (2015). School-based social capital: The missing link between schools' socioeconomic composition and collective teacher efficacy. Teaching and Teacher Education, 45, 33-44. https://doi.org/ 10.1016/j.tate.2014.09.001 
Bentler, P.M., \& Bonett, D.G. (1980). Significance tests and goodness of fit in the analysis of covariance structures. Psychological Bulletin, 88(3), 588-606. https://psycnet.apa.org/do $\mathrm{i} / 10.1037 / 0033-2909.88 .3 .588$

Best, J.W., \& Kahn, J.V. (2017). Eğitimde araştırma yöntemleri [Research methods in education], (O. Köksal, Çev.). Eğitim Yayınevi.

Blatti, T., Clinton, J., \& Graham, L. (2019). Exploring collective teacher efficacy in an international school in Shanghai. International Journal of Learning, Teaching and Educational Research, 18(6), 214-235. https://doi.org/10.26803/ijlter.18.6.13

Borgogni, L., Petitta, L., \& Mastrorilli, A. (2010). Correlates of collective efficacy in the Italian Air Force. Applied Psychology, 59(3), 515-537. https://doi.org/10.1111/j.14640597.2009.00410.x

Brown, T.A. (2006). Confirmatory factor analysis for applied research. Guilford Press.

Büyüköztürk, Ş. (2002). Faktör analizi: Temel kavramlar ve ölçek geliştirmede kullanımı [Factor analysis: Basic concepts and using to development scale]. Educational Administration: Theory and Practice, 8(4), 470-483.

Büyüköztürk, Ş. (2012). Sosyal bilimler için veri analizi el kitabı [Manual of data analysis for social sciences] (16. Bask1). Pegem Akademi.

Büyüköztürk, Ş., Kılıç Çakmak, E., Akgün, Ö.E., Karadeniz, Ş. \& Demirel, F. (2018). Bilimsel araştırma yöntemleri [Scientific research methods] (25. Bask1). Pegem Akademi.

Byrne, B.M., \& Campbell, T.L. (1999). Cross-cultural comparisons and the presumption of equivalent measurement and theoretical structure: A look beneath the surface. Journal of Cross-Cultural Psychology, 30(5), 555-574. https://doi.org/10.1177/0022022199030005 001

Carroll, J.M., Rosson, M.B., \& Zhou, J. (2005, April). Collective efficacy as a measure of community. In Proceedings of the SIGCHI conference on human factors in computing systems (pp. 1-10). https://doi.org/10.1145/1054972.1054974

Crowley, S.L., \& Fan, X. (1997). Structural equation modeling: Basic concepts and applications in personality assessment research. Journal of Personality Assessment, 68(3), 508-531. https://doi.org/10.1207/s15327752jpa6803 4

Çelik, K., Gören, T., \& Kahraman, Ü. (2018). The relationship between elementary school teachers' levels of collective efficacy and morale levels. Journal of Human Sciences, 15(4), 2644-2656. https://doi.org/10.14687/jhs.v15i4.5651

Çokluk, Ö., Şekercioğlu, G., \& Büyüköztürk, Ş. (2012). Sosyal bilimler için çok değişkenli istatistik SPSS ve LISREL uygulamalart [Multivariate statistics for social sciences: SPSS and LISREL applications] (2.Bask1). Pegem Akademi.

DeVellis, R.F. (2017). Scale development theory and applications. Sage Publications.

Doğan, M. (2013). Doğrulayıcı faktör analizinde örneklem hacmi, tahmin yöntemleri ve normalliğin uyum ölçütlerine etkisi [Influence of sample size, estimation method and normality on fit indices in confirmatory factor analysis] [Unpublished master's thesis]. Eskişehir Osmangazi University.

Demir, S. (2019). Kolektif öğretmen yeterliğinin öğretmen iş doyumundaki rolü üzerine yapısal eşitlik modellemesi [Structural equation modeling on the role of teacher's collective efficacy in teacher job satisfaction]. OPUS Uluslararası Toplum Araştırmaları Dergisi, 10(17), 444-463. https://doi.org/10.26466/opus.496333

Donohoo, J. (2017). Collective teacher efficacy research: Implications for professional learning. Journal of Professional Capital and Community, 2(2), 101-116. https://doi.org/10.1108/JPCC-10-2016-0027

Donohoo, J. (2018). Collective teacher efficacy research: Productive patterns of behaviour and other positive consequences. Journal of Educational Change, 19(3), 323-345. https://doi.org/10.1007/s10833-018-9319-2 
Donohoo, J., Hattie, J., \& Eells, R. (2018). The power of collective efficacy. Educational Leadership, 75(6), 40-44.

Eells, R.J. (2011). Meta-analysis of the relationship between collective teacher efficacy and student achievement [Unpublished doctoral dissertation]. Loyola University.

Erdoğan, U., \& Dönmez, B. (2015). Kolektif öğretmen yeterliği ölçeğinin Türkçeye uyarlanması: Geçerlik ve güvenirlik çalışması [Adaptation of collective teacher efficacy scale into Turkish: Validity and reliability study]. Kuram ve Uygulamada Eğitim Yönetimi Dergisi, 21(3), 345-366. http://dx.doi.org/10.14527/kuey.2015.013

Goddard, R.D., Hoy, W.K., \& Hoy, A. W. (2000). Collective teacher efficacy: Its meaning, measure, and impact on student achievement. American Educational Research Journal, 37(2), 479-507. https://doi.org/10.3102/00028312037002479

Goddard, R. (2002). A theoretical and empirical analysis of the measurement of collective efficacy: The development of a short form. Educational and Psychological Measurement, 62(1), 97-110. https://doi.org/10.1177/0013164402062001007

Goddard, R.D., Hoy, W.K., \& Hoy, A.W. (2004). Collective efficacy beliefs: Theoretical developments, empirical evidence, and future directions. Educational Researcher, 33(3), 3-13. https://doi.org/10.3102/0013189X033003003

Goddard, R.D., LoGerfo, L., \& Hoy, W.K. (2004). High school accountability: The role of perceived collective efficacy. Educational Policy, 18(3), 403-425. https://doi.org/10.1 $\underline{177 / 0895904804265066}$

Guskey, T.R., \& Passaro, P.D. (1994). Teacher efficacy: A study of construct dimensions. American Educational Research Journal, 31(3), 627-643. https://doi.org/10 $.3102 / 00028312031003627$

Gürçay, D., Yılmaz, M., \& Ekici, G. (2009). Öğretmen kolektif yeterlik inancını yordayan faktörler [Factors predicting teachers' collective efficacy beliefs]. H. U. Journal of Education, 36(36), 119-128.

İlhan, M., \& Çetin, B. (2014). Sınıf değerlendirme atmosferi ölçeğinin (SDAÖ) geliştirilmesi: Geçerlik ve güvenirlik çalışması [Development of classroom assessment environment scale (CAES): Validity and reliability study]. Education and Science, 39(176), 31-50 http://dx.doi.org/10.15390/EB.2014.3334

İslamoğlu, A.H., \& Alnıaçık, Ü. (2016). Sosyal bilimlerde araştırma yöntemleri [Research methods in social sciences] (5.Bask1). Beta Yayınları.

Kalayc1, S. (2006). SPSS uygulamalı çok değişkenli istatistik teknikleri [Multivariate statistical techniques with SPSS applied]. Asil Yayınevi.

Karagöz, Y. (2017). SPSS ve AMOS uygulamalı nicel-nitel-karma bilimsel araştırma yöntemleri ve araştırma etiği [SPSS and AMOS applied quantitative-qualitative-mixed scientific research methods and research ethics]. Nobel Yayıncılık.

Karaman, H. (2015). Açımlayıcı faktör analizinde kullanılan faktör çıkartma yöntemlerinin karşılaştırılması [The comparison of factor extraction strategies used in exploratory factor analysis] [Unpublished master's thesis]. Hacettepe University.

Karaman, H., Atar, B., \& Çobanoğlu Aktan, D. (2017). Açımlayıcı faktör analizinde kullanılan faktör çıkartma yöntemlerinin karşılaştırılması [The comparison of factor extraction strategies used in exploratory factor analysis]. Gazi University Journal of Gazi Educational Faculty (GUJGEF), 37(3), 1173-1193.

Koçak, S., \& Özdemir, M. (2019). Kolektif öğretmen yeterliğinin dört çerçeve liderlik modeli perspektifinden değerlendirilmesi [Evaluation of collective teacher efficacy from the perspective of four-frame leadership model]. Education and Science, 45(203), 347-365. http://dx.doi.org/10.15390/EB.2019.8325

Kurt, T. (2009). Okul müdürlerinin dönüşümcü ve işlemci liderlik stilleri ile ögretmenlerin kolektif yeterliği ve öz yeterliği arasındaki ilişkilerin incelenmesi [Examination of 
relationships between transformational and transactional leadership styles of school principals and collective efficacy and self-efficacy of teachers] [Unpublished doctoral dissertation]. Gazi University.

Kurt, T. (2012). Öğretmenlerin öz yeterlik ve kolektif yeterlik algıları [Self-efficacy and collective-efficacy perceptions of teachers]. Türk Ĕ̈itim Bilimleri Dergisi, 10(2), 195227.

Lee, J. C.K., Zhang, Z., \& Yin, H. (2011). A multilevel analysis of the impact of a professional learning community, faculty trust in colleagues and collective efficacy on teacher commitment to students. Teaching and Teacher Education, 27(5), 820-830. https://doi.org/10.1016/j.tate.2011.01.006

Lee, V.E., \& Smith, J.B. (1996). Collective responsibility for learning and its effects on gains in achievement for early secondary school students. American Journal of Education, 104(2), 103-147. https://doi.org/10.1086/444122

Liu, Y. (2003). Developing a scale to measure the interactivity of websites. Journal of Advertising Research, 43(2), 207-216. https://doi.org/10.2501/JAR-43-2-207-216

Nunally, J.C., \& Bernstein, I.H. (1978). Psychometric theory -25 years ago and now. Educational Researcher, 4(10), 7-21. https://doi.org/10.3102/0013189X004010007

Özcan, S. (2017). Özgün (authentic) liderliğin duygusal örgütsel bă̆lllı üzerindeki etkisinde işyerindeki esenlik, kolektif yeterlik ve kurumsal itibar değişkenlerinin rolü [The mediating roles of well-being at work, collective efficacy and organizational reputation in the relationship between authentic leadership and affective organizational behaviour] [Unpublished doctoral dissertation]. Gebze Teknik University.

Pallant, J. (2007). SPSS survival manual: A step by step guide to data analysis using the SPSS program (3. Edition). McGraw Hill.

Parker, K., Hannah, E., \& Topping, K.J. (2006). Collective teacher efficacy, pupil attainment and socio-economic status in primary school. Improving Schools, 9(2), 111-129. https://doi.org/10.1177/1365480206064965

Pedhazur, E. J., \& Pedhazur Schmelkin, L. (1991). Measurement, design and analysis: An integrated approach. Taylor \& Francis Group.

Pepe, S., Sobral, J., Gómez-Fraguela, J.A., \& Villar-Torres, P. (2008). Spanish adaptation of the adolescents' perceived collective family efficacy scale. Psicothema, 20(1), 148-154.

Ramos, M.F.H., Costa, S.S., Pontes, F.A. R., Fernandez, A.P.O., \& Nina, K.C.F. (2014). Collective teacher efficacy beliefs: A critical review of the literature. International Journal of Humanities and Social Science, 4(7), 179-188.

Ross, J., \& Bruce, C. (2007). Professional development effects on teacher efficacy: Results of randomized field trial. The Journal of Educational Research, 101(1), 50-60. https://doi.org/10.3200/JOER.101.1.50-60

Ross, J.A., Hogaboam-Gray, A., \& Gray, P. (2003, April ). The contribution of prior student achievement and school processes to collective teacher efficacy in elementary schools [Conference presentation abstract]. American Educational Research Association, Chicago, IL, United States.

Ross, J.A., \& Gray, P. (2006). Transformational leadership and teacher commitment to organizational values: The mediating effects of collective teacher efficacy. School Effectiveness and School Improvement, 17(2), 179-199. https://doi.org/10.1080/0924345 0600565795

Schechter, C., \& Tschannen-Moran, M. (2006). Teachers' sense of collective efficacy: an international view. International Journal of Educational Management, 20(6), 480-489. https://doi.org/10.1108/09513540610683720

Schumacker, R. E. \& Lomax, R. G. (2010). A beginner's guide to structural equation modeling. Taylor \& Francis Group. 
Schwarzer, R., \& Jerusalem, M. (1999). Skalen zur Erfassung von Lehrer- und Schülermerkmalen: Dokumentation der psychometrischen Verfahren im Rahmen der wissenschaftlichen Begleitung des Modellversuchs Selbstwirksame Schulen. Freie Universität Berlin.

Tabachnick, B.G., \& Fidel, L.S. (2001). Using multivariate statistics. (4. Edition). Allyn \& Bacon, Inc.

Tabachnick, B.G., \& Fidell, L.S. (2012). Using multivariate statistics (6. Edition). Pearson.

Tezbaşaran, A.A. (1997). Likert tipi ölçek geliştirme kılavuzu [Likert scale development guide]. Türk Psikologlar Derneği.

Tschannen-Moran, M., \& Barr, M. (2004). Fostering student learning: The relationship of collective teacher efficacy and student achievement. Leadership and Policy in Schools, 3(3), 189-209. https://doi.org/10.1080/15700760490503706

Turhan, M., \& Yaraş, Z. (2014). İlkokul yöneticilerinin program liderliği davranışlarını gösterme düzeylerinin öğretmenlerin kolektif yeterlik algısına ve örgütsel öğrenme düzeyine etkisi [The influence of instructional leadership behavior of school administrators on perceived collective competencies of teachers and the level of organizational learning]. Journal of Educational Sciences, 39, 175-193. https://doi.org/10.15285/EBD.2014397404

Uğurlu, C.T., Beycioğlu, K., \& Abdurrezzak, S. (2018). Bilgi okuryazarlığı, kolektif öğretmen yeterliği ve etkili okul: Yapısal eşitlik modellemesi [Information literacy, collective teacher adequacy and effective school: Structural equation modeling]. Elementary Education Online, 17(4), 1988-2005.

Uyar, S. (2012). Açımlayıcı faktör analizinde boyut sayısını belirlemede kullanılan yöntemlerin karşılaştırllması [Comparision of procedures for determining the number of dimensions in exploratory factor analysis] [Unpublished master's thesis]. Hacettepe University.

Ware, H., \& Kitsantas, A. (2007). Teacher and collective efficacy beliefs as predictors of professional commitment. The Journal of Educational Research, 100(5), 303-310. https://doi.org/10.3200/JOER.100.5.303-310

Yılmaz, M., \& Turanlı, N. (2017). Öğretmenlerin kolektif yeterlik algılarının incelenmesi: Altındağ ilçesi örneği [Examination on teachers' collective efficacy perception: Altındag district sample]. The Journal of International Lingual Social and Educational Sciences, 3(2), 151-158.

Yılmaz, M. \& Uslu, Ö. (2018). Güdülenmiş öğrenmeyi destekleme öz-yeterlik algısının kollektif yeterlik, tükenmişlik ve teknolojiyle bütünleşmeyle ilişkisi [Relationship between supporting motivated learning self-efficacy, collective efficacy, burn-out and technology integration]. Ege Journal of Education, 19(1), 225-244. https://doi.org/10.12 984/egeefd. 375587

Yorulmaz, R., \& Erdem, R. (2017). Hastane çalışanlarında kontrol odağının öz ve kolektif yeterlilik üzerine etkisi [The effect on self and collective efficacy of locus of control in the hospital employess]. Visionary E-Journal, 8(19), 77-92. https://doi.org/10.21076/viz yoner.317182 


\section{APPENDIX}

\section{The Collective Teacher Efficacy Behaviours Scale (CTEBS)}

\begin{tabular}{|c|c|c|c|c|c|c|c|}
\hline $\begin{array}{l}\stackrel{\Xi}{0} \\
\stackrel{0}{0} \\
\stackrel{0}{0}\end{array}$ & $\stackrel{\stackrel{\circ}{Z}}{\stackrel{\Xi}{ \pm}}$ & $\begin{array}{l}\text { All of us as teachers ... } \\
\text { Öğretmenler olarak hepimiz... }\end{array}$ & 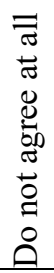 & 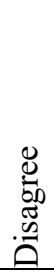 & 莺 & 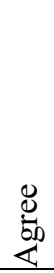 & 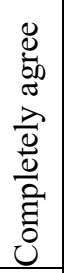 \\
\hline \multirow{15}{*}{ 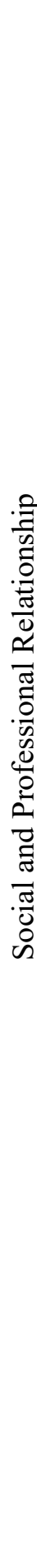 } & 1 & $\begin{array}{l}\text {... are with our fellow teachers in their special occasions and hard times. } \\
\text {...ögretmen arkadaşlarımızın özel ve zor günlerinde yanında oluruz. }\end{array}$ & & & & & \\
\hline & 2 & $\begin{array}{l}\text {... have a dynamic relationship with our colleagues. } \\
\text {...meslektaşlarımızla aramızda dinamik bir ilişki vardır. }\end{array}$ & & & & & \\
\hline & 3 & $\begin{array}{l}\ldots \text { act synergistically. } \\
\ldots \text { sinerjik bir şekilde hareket ederiz. }\end{array}$ & & & & & \\
\hline & 4 & $\begin{array}{l}\ldots \text { work in coordination. } \\
\text {...eşgüdüm halinde görev yaparız. }\end{array}$ & & & & & \\
\hline & 5 & $\begin{array}{l}\text {... have discussions with our colleagues to improve teaching activities. } \\
\text {...̈̈gretim faaliyetlerinin geliştirilmesi için meslektaşlarımızla tartışmalar } \\
\text { yaparız. }\end{array}$ & & & & & \\
\hline & 6 & $\begin{array}{l}\text {... frequently communicate with our colleagues to support our students' } \\
\text { development. } \\
\text {...öğrencilerimizin gelişimlerini desteklemek amacıyla meslektaşlarımızla } \\
\text { sık sık iletişime geçeriz. }\end{array}$ & & & & & \\
\hline & 7 & $\begin{array}{l}\text {... unite when a colleague of us is exposed to an unfairness. } \\
\text {... bir meslektaşımıza karş1 adaletsiz bir durum olduğunda birlik oluruz. }\end{array}$ & & & & & \\
\hline & 8 & $\begin{array}{l}\text {... organize various outdoor activities (trips, social events, etc.) with our } \\
\text { colleagues. } \\
\text {...meslektaşlarımızla okul dışı zamanlarda çeşitli etkinlikler (gezi, sosyal } \\
\text { etkinlik vb.) düzenleriz. }\end{array}$ & & & & & \\
\hline & 9 & $\begin{array}{l}\text {... express opinions in decisions concerning the entire school. } \\
\text {...okulun tamamin ilgilendiren kararlarda fikirlerimizi belirtiriz. }\end{array}$ & & & & & \\
\hline & 10 & $\begin{array}{l}\text {... find solutions to the in-school problems with a common sense. } \\
\text {...okul içerisinde meydana gelen problemler karşısında çözüm yollarını } \\
\text { ortak akılla buluruz. }\end{array}$ & & & & & \\
\hline & 11 & $\begin{array}{l}\text {... share with our colleagues when we learn new professional knowledge. } \\
\text {...mesleki anlamda yeni bir bilgi öğrendiğimizde bu bilgiyi } \\
\text { meslektaşlarımızla paylaşırız. }\end{array}$ & & & & & \\
\hline & 12 & $\begin{array}{l}\text {... try to help each other improve their teaching methods and techniques. } \\
\text {...birbirimize öğretim yöntem ve tekniklerini geliştirmeleri konusunda } \\
\text { yardımcı olmaya çalışırız. }\end{array}$ & & & & & \\
\hline & 13 & $\begin{array}{l}\text {... ask for feedback from teacher colleagues at school in improving } \\
\text { education. } \\
\text {...okulumuzdaki meslektaşlarımızdan eğitim-öğretimin geliştirilmesi ile } \\
\text { ilgili geri bildirim alırız. }\end{array}$ & & & & & \\
\hline & 14 & $\begin{array}{l}\ldots \text { trust each other in professional matters. } \\
\text {...birbirimize mesleki konularda güveniriz. }\end{array}$ & & & & & \\
\hline & 15 & $\begin{array}{l}\text {... attempt to motivate our students in their learning process. } \\
\text {...öğrencilerimizi öğrenme süreçlerinde motive etmek için çaba sarf ederiz. }\end{array}$ & & & & & \\
\hline
\end{tabular}




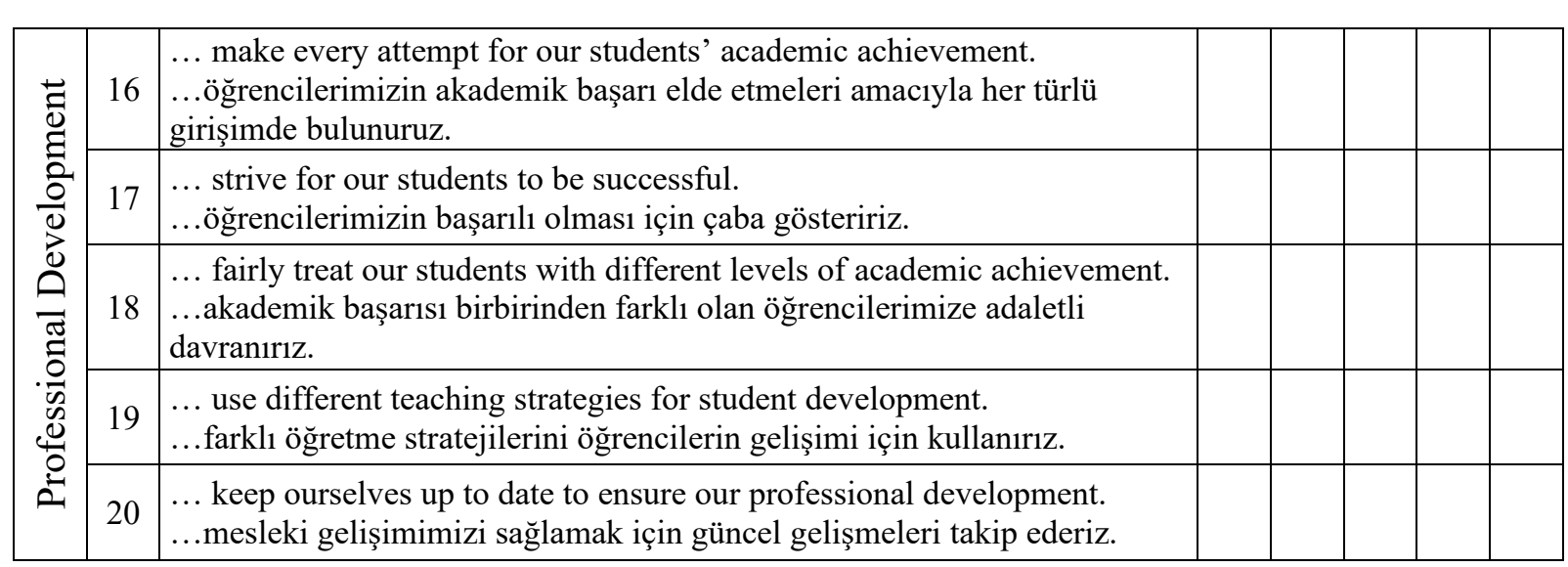

